\title{
Online Learning during Corona Virus Epidemic in Saudi Arabia: Students' Attitudes and Complications
}

\author{
Dr. Azzah Alghamdi \\ Yanbu Education Administration, Yanbu, Saudi Arabia \\ E-mail:alghamdiazzahdr@gmail.com \\ Dr. Musa Alghamdi \\ English language and prep. Year Institution - Royal Commission, Yanbu, Saudi Arabia \\ E-mail:alghamdimu@rcyci.edu.sa
}

\begin{abstract}
Covid19 epidemic impacts all sides of life worldwide, and education is one of these sides that have been dramatically affected. During this epidemic, the Ministry of Education in Saudi Arabia obliged students to commence online learning from homes without conventional (face-to-face) education. These dramatic and sudden changes in the education system may affect the students and their inclination towards online classrooms. Thus, this study aimed to investigate students' attitudes towards using online learning and the challenges facing them during the coronavirus epidemic in Saudi Arabia. Moreover, it aimed to explore the gender differences regarding students' ICT competence and their attitudes towards using online learning. One thousand three hundred eighty-seven students (616 females and 771 males) from different school level (elementary to postgraduate) participated in the current study. The researchers employed two data collection instruments (questionnaire and semi-structured interviews) during this study. However, this paper only focused on the quantitative results. The outcomes of this study indicated that the participants showed high positive attitudes towards using online learning during the Covid19 period. The top-highest difficulties that faced students during online learning were the weakness of the internet connection, unavailability of good quality devices, unavailability of the internet connection for some students, and technical problems. Moreover, the findings indicated gender-related differences in students' ICT competence and their attitudes about using online learning.
\end{abstract}

Keywords: Distance (online) learning/ (Covid19) coronavirus epidemic/ Students' attitudes/ Difficulties when using technology/ Gender.

DOI: $10.7176 / \mathrm{JEP} / 12-17-03$

Publication date:June $30^{\text {th }} 2021$

\section{INTRODUCTION}

Online learning has significantly developed in the last decade. According to Shao (2019), online education creates four main opportunities for learners to enhance their education. It creates an ample opportunity to augment the autonomy and independent learning among learners. As well, it gives students both the time and places freedom to approach learning resources and materials. Moreover, online education offers excellent chances for learners to raise the level of interaction with their teachers. Besides, it paves the way for the learners to cooperate and share their works and experience with other learners (Shao, 2019).

Individuals can note to what extent the international textbooks' publishers have published new versions of their books integrated with online-based materials. However, online materials are always embedded in conventional classrooms to help teachers and students to carry out the teaching and learning process (blended learning). The serious challenge that educators worldwide, was thinking about and hesitated to take up was only on solo online learning. Although some educational institutions have taken this challenge, most of the international institutions hesitated to do so.

No doubt that covid19 has its impact on all ways of life worldwide. Education is one of the sides of life that have been greatly affected by Covid19. Most of the countries have sent their students home and stopped school attendance. Online learning was the one solution that most education authorities were thinking about during Covid19 time to educate their students. Consequently, during Covid19, students in Saudi Arabia have been asked not to attend schools and commence online learning suddenly and without any preparation.

Implement online learning entails several procedures, among which are pre-assessing students' perceptions and attitudes, necessary technical and pedagogical help, and technical facilities (hardware and software) to offer better teaching and learning. Thus, this study aims to identify the viewpoints and attitudes of students as well as the challenges faced them during the coronavirus epidemic in Saudi Arabia. It also aims to explore the gender differences regarding students' ICT competencies and their attitudes towards using online learning during the Covid19 time. 


\section{LITERATURE REVIEW}

\subsection{Online Learning}

It is evident through the literature that both the experts and scholars could not reach clear definitions and terminologies for online learning (Lowenthal \& Wilson, 2010). So, the previous literature has used terminologies such as e-learning, distance learning, online learning and web-based learning. The current study utilizes online learning because it may include all the meaning of those terminologies. It is distance learning where students study their courses away from their regular classrooms. It is e-learning because students use some technologies to access their courses contents (Carliner, 2004). It is web-based learning because learners use internet websites or internet-enhanced applications and systems to $\log$ in to their materials. According to Means et al. (2010), online learning is defined as the learning and teaching process that occurs partially or wholly via the World Wide Web.

Furthermore, previous literature has clarified that online learning provides learners with two types of environments. These are synchronous and asynchronous (e.g. Dahlstrom-Hakki et al., 2020). synchronous means real-time online learning (e.g. podcasting lessons over video conferencing), while asynchronous is not real-time online learning (e.g. contact over email).

Moreover, previous studies have divulged numerous benefits that can be gained by exploiting online learning (e.g. Al-Qahtani, 2011; Hameed et al., 2008; Marc, 2002). Hone \& El Said (2016) state that one of the most beneficial benefits that online learning can provide the learner is creating a chance for students to reach global educational resources. Moreover, Moor (2013) mentions that online learning has several advantages. These advantages include the ability of online learning to allow learners to be flexible in the level of time and place to access online classes. Moreover, online learning fostered self-dependent and autonomy among learners (Moore, 2013; Lee, 2016).

In addition to the advantages that have been mentioned above, online learning can increase the amount of learners' communication. Balaji and Chakrabarti (2010) conduct an investigation that aims to discover the potentials of the online environment theories such as 'Theory of Online Learning' (Anderson, 2004) and 'Media Richness Theory' (Daft and Lengel, 1986) to be used to explain the learners' communication in the web-based discussion forum. As well, they examined the role of online interaction on observed learning. They propose that web-based discussion forum, besides the conventional classes, enhance learners with a productive interaction environment and, in turn, enables effective learner communication and education. To conduct this study, the researchers create a web-based discussion forum to increase learning activities out of a conventional classroom environment. Two hundred twenty-seven participants participated in this study. Those participants joined four class sections in the MBA program of a leading private university in India from January 2008 through December 2008. This study suggests that instructors play a significant role to facilitate learners' interactions in web-based discussion forums. Moreover, the study proves that online feedback has a substantial influence on learners' communication.

\subsection{Learners' Readiness to use Technology}

The literature has raised the importance of investigating the students' readiness for online education before commencing their courses. Guglielmino and Guglielmino (2003) have clarified that learner readiness is a level at which a learner can utilize online learning. Different researchers have used other measurements to assess learners' readiness for online learning. One of these measurements is "Readiness for Education At a Distance Indicator (READI, now known as Smarter Measure)". This measurement is mainly used by the higher education establishment to uncover their learners' preparedness before they were commencing any online course (Mehran et al., 2017, p. 2). The Smarter Measure measures the readiness of the learners by focusing on five abilities: individual attributes, learning styles, typing speed and accuracy, on-screen reading speed and comprehension, and technical competency skills (Smarter Measure Assessment, 2020).

On the other hand, some other researchers have used their questionnaire to measure the readiness of the learners to deal with the needed technologies. In the current research, the last ability (technical competency skills) has been under consideration when the researchers designed their questionnaire. Thus, the present study aims to measure learners' technical competency through selected seven technical skills: computer use competence, learners' abilities to use virtual classrooms, their skills to use virtual platforms, their expertise in using search engines, their skills in using email, their knowledge of internet security threats and their knowledge to follow internet security procedures.

\subsection{Students' Attitudes towards using Online Learning}

Several prior studies indicated that attitude plays a chief role in the learning process (Arbaugh, 2010), and therefore, several studies have investigated the learners' attitudes towards online and technical-enhanced learning. Bichi et al. (2017) used ICT Attitude and Competence Questionnaire (IACQ) to investigate the attitudes of 77 Nigerian postgraduate students towards information and communication technology (ICT) and their perceived 
competence in using ICT resources for research purpose. The participants showed a positive inclination towards technology-based learning, and they clarify that they are skilled in using essential ICT components. However, this study found that postgraduate learners need more experiences and training to be able to expand their skills in using ICT. Abedalaziz et al. (2013) studied the predisposition of 289 college students at the University of Malaya towards the implementation of PC and the internet in learning and education. The study uncovered that learners' positive inclination towards the use of technology as well as, they had a strong impression of their mastering the different aspects of that technology. The researchers found no gender-related differences in the participants' inclination towards technology. However, the age of the participants played a role in their tendency towards technology, where the younger participants showed more preference than elders.

Xing et al. (2020) investigated nurse students' inclinations toward e-learning. Moreover, they focused on identifying aspects that stimulate or restrain their inclination towards e-learning. The researchers distributed a questionnaire to 534 registered nurses in Shanghai hospitals. The study found that the essential encouraging aspect was the flexibility that e-learning may provide. On the other hand, lack of time to participate in e-learning was the most shared obstacle among the participants. Moreover, the result highlighted that $50 \%$ of the participants showed a positive predisposition to e-learning. Huss \& Eastep (2013) conducted research to study the attitudes and perceptions of learners towards online learning via sending an electronic survey to 1085 students. The participants, at least, are enrolled in one online course during the fall 2012 semester. The research concentrated on learners' views about internet-based teaching. As well as, it focused on learners' anticipations and knowledge in the areas such as "course format, technological support, interaction with faculty and peers, course flexibility and pace, assessment and feedback, and overall communication" (Huss \& Eastep, 2013, p.2). The findings indicated that $68 \%$ of the participants felt comfortable in using online learning, while $32 \%$ did not. The participants showed a positive and negative inclination towards some elements. They showed a positive disposition towards technology elements that are made by teachers (tutorials, audio and video lectures). Still, they displayed negative attitudes towards technology elements that they use by themselves (e.g. opening files or using different browsers).

Webb \& Doman (2020) conducted three-year research to study attitudes towards technology-enhanced language learning (TELL) in the flipped classroom in three different areas (USE, Colombia and Macau). The researchers applied three data collection tools (technology survey, focus group sessions, and reflective essays). The study revealed that the experimental group from the USA was always significantly different in all survey elements of attitudes towards TELL. As well, the findings uncovered the positive attitude of the participants in the flipped classroom toward flipped learning than the participants in the non-flipped ones. This result may reflect the effect of the existence of the participants in the flipped classrooms for a while on their attitudes. In other words, one may conclude that as a student exists in a technology-enhanced education environment, by the time, he or she will adopt a positive attitude towards that technology.

Jebur (2020) aims to study learners' attitudes towards the use of smartphones in education. The researcher distributed two surveys to 237 students in the English language department. The first survey focused on learners' attitudes, and the second survey focused on the use of mobile in education. The study found that the students have positive attitudes towards using smartphones for learning.

Williams and Pury (2002) investigated learners' views towards an electronic collaboration tool known as "Collaborative Learning Environment" (CLE), which was used at Clemson University. Moreover, they investigated reasons that prevent learners from utilizing the CLE to interact with each other instead of only answering teachers' questions. The researchers used an e-survey to gather learners' views about five items. These items focused on a number of topics. These topics included the extent to which learners find the web-based discussion joyful; a number of replies posted by learners; how often learners use the discussion platform to ask questions or discuss debatable issues; the degree to which learners prefer the discussion tools; and the number of topics that learners read. A questionnaire was distributed to two groups of participants (mandatory and optional). The findings of this study indicated that the learners from both groups found web-based discussion was unjoyful. However, the participants did not consider it a waste of time. They reported that the web-based discussion allows them to ask questions and technical enquiries; or discuss debatable topics.

Ozaydin Ozkara and Cakirb (2018) studied the aspects that affect the contribution in web-based classes from the learners' point of views. They applied a qualitative investigation about learners' practices to increase communication in a web-based setting. They divided participants into two groups. The first group included 15 participants who worked based on collaboration. The second group included 15 participants who worked individually. Data was gathered via interviews and reflection reports. The result found that web-based participation was influenced by personal approaches, changing variables, mediated attributes. The two groups of participants found that the web-based classes were enjoyable.

The previous literature raised some difficulties and challenges that may encounter learners in online classes. 
Online assistance and technical support were among the challenges that were introduced in the literature. Technical support plays a vital job during online learning. They can encourage learners in an online learning context by lessening their anxiety. Moreover, they have an enormous effect on the value of the education process during online learning (Markova et al., 2017). According to Markova et al. (2017), above 40\% of participants were either not pleased with the level of technical support provided during their course or difficulty evaluating that support. According to Cross (2018), learners in online classes may feel lost because the only way to get help is through either intricate links or telephone line to contact an unknown person who can or cannot provide support. The other problem is that this help may not be delivered immediately when learners need help. Students consider and value educational advice-givers who has four main advantages. They can provide rapid answers for learners' enquiries, knowledgeable about educational requirements and strategies, provide assistance for learners to achieve academic development during their study, and display acceptable behaviours (Cross, 2018). The other challenge that encounters learners in online courses is the absence of technical support. Technical support is vital for learners during online courses (Kenney \& Newcombe, 2010; Heaney \& Walker, 2012; Gedik et al., 2013; Lotrecchiano et al., 2013).

Bloomfield \& Jones (2013) conducted a study to explore first-year students' opinions about online learning course and their practices during the course that was used to supplement traditional methods. The result of their study showed that although the participants had a positive view of online learning, they did not want to abandon traditional classes. The most significant online learning feature for the participants was video clips, while webbased readings were considered the least beneficial. On the other hand, they feel frustrated because of underestimating time requirements, navigational issues and technical difficulties. $\mathrm{Ng}$ (2007) conducted research to study the implementation of an asynchronous technical-enhanced system (Interwise) for online courses provided by Open University of Hong Kong. In this research, six instructors and eight learners were interviewed. The study found that both instructors and learners had a positive view about using the system for online courses. However, two challenges appeared during this research. First, the interaction among learners was insignificant. Second, several of the participants raised that the technical difficulties reduced the learning process. One of the technical difficulties encountered by learners during online courses was the internet connection. Both the absence and weaknesses of bandwidth transmission have posed a major challenge for the online learning process (Alebaikan \& Troudi, 2010; Ramos et al., 2011). Heaney \& Walker (2012) reported that one of the challenges encountered in online courses is technical-related difficulties such as the fault or weaknesses of the internet connection. In the same vein, Ramos et al. (2011) found that the low internet connection in the teachers' offices was a major reason that restricted their abilities to participate in online courses.

\subsection{Gender and Technology-enhanced Education}

Lowes et al. (2017) found that gender differences are apparent in online posts during 14 online courses. The researchers investigate gender-related differences in the relationships between learners' online behaviours and academic performance during those courses. McSporran and Young (2001) studied college students during an internet pages' design course. In their web-based classes, female learners participated more than males. The female learners surpassed males in assignments, self-regulation, and performance. Liang et al. (2015) compared two types of discussions contexts (online and face-to-face). They uncover that both genders (male and female) perform differently in both settings. Their study found that male and female learners used similar discussion approaches during a face-to-face context. However, females demonstrated more ability to provide further elaboration than males in web-based discussions.

Furthermore, female learners are inclined to join online courses more than male learners because of the flexibility of such courses that help them undertake other responsibilities (Xu \& Jaggars, 2011). Although previous research reveals an association between female learners and success in their web-based courses (e.g. Xu \& Jaggars, 2013) other investigations uncover that they either fail or do not complete their online courses (e.g. Wladis et al., 2015). Sarfo et al. (2011) investigated the attitudes of Senior High Schools learners towards information and communication technology (ICT). 324 students from two urban and rural in Ghana participated in this study by filling in a questionnaire. This study aims to measure the learners' inclination towards ICT for augmented growth policy in Ghana's education to obtain ICT competence and applying ICT to stimulate education process. This study raised no gender-related difference in the participants' attitudes.

Aesaert \& Van Braak (2015) used a computer and performance-based evaluation test to investigate elementary school learners' technology skills. They studied the association between sex and the socioeconomic situation on one side and the learners' results on the test on the other side. Three hundred seventy-eight sixthgrade learners of 58 elementary schools participated in this study. This investigation indicated that elementary school learners encountered some difficulties in higher-order technology skills. In other words, the participants found it challenging to use interactive methods that are accepted understood by society members. Furthermore, female learners showed better technological competence than male learners. In addition, the findings demonstrated that mothers' educational background positively correlate with both learners' technology 
competence and their higher-order ICT skills.

\section{RESEARCH AIMS}

This study targets to investigate students' attitudes towards using online learning and the challenges facing them during the coronavirus epidemic in Saudi Arabia. It also explores the gender differences regarding their ICT competencies and their attitudes during the coronavirus epidemic in Saudi Arabia.

\section{RESEARCH QUESTIONS}

1) What are the views of students towards using online learning during the coronavirus epidemic in Saudi Arabia?

2) What difficulties and challenges faced students in using online learning during the coronavirus epidemic in Saudi Arabia?

3) Are there gender-related differences in students' competencies in using online learning during the coronavirus epidemic in Saudi Arabia?

4) Are there gender-related differences in attitudes towards using online learning during the coronavirus epidemic in Saudi Arabia?

\section{RESEARCH METHODOLOGY}

\subsection{Research Design}

This study used a mixed-methods approach to investigate students' views towards using online learning and the challenges faced during the coronavirus epidemic. Questionnaire and semi-structured interviews were applied to collect data in this study. The sequential explanatory strategy was employed in this study, as suggested by Creswell et al. (2003), where a questionnaire was used first to collect quantitative data to gain general information about students' views. Followed by qualitative data obtained by using interviews to gather more details and explanations regarding students' answers. Quantitative data were analyzed by using SPSS software program, whereas qualitative data were analyzed by using thematic analysis method. However, in this paper, only the quantitative data will be presented.

\subsection{Sample}

One thousand three hundred eighty-seven students (616 females and 771 males) completed the questionnaire. Those students were from different school stages, from elementary to postgraduates. There were 335 students (24.2\%) from elementary schools and 145 students (10.5\%) from intermediate schools. Moreover, $336(24.2 \%)$, $539(38.9 \%)$, and $32(2.3 \%)$ students were in secondary, undergraduate, and postgraduate levels, respectively. Regarding the interviewees, twenty students from various school stages participated in this study.

\subsection{Reliability and Validity}

The reliability of the questionnaire was tested before distribution. Face validity and content validity for the questionnaire were tested during a pilot study with eleven students. Moreover, Cronbach's Alpha coefficients were conducted for all the questionnaire subscales to check the internal consistency (Cohen et al., 2007). It was measured as $(\alpha=0.847)$ (Table 1$)$, which indicated an acceptable level of reliability.

Table 1. Cronbach's alpha coefficients for the subscales of the questionnaire

\begin{tabular}{|c|c|c|}
\hline \multicolumn{2}{|c|}{ Reliability Statistics } \\
\hline Cronbach's Alpha & Cronbach's Alpha Based on Standardized Items & N of Items \\
\hline 0.847 & 0.839 & 20 \\
\hline
\end{tabular}

\subsection{Data Analysis}

The quantitative data in this study were analyzed using the SPSS (v 19) software program by applying descriptive statistics (Mean, mode, median, and standard deviations). Additionally, Chi-Square and Fisher's exact tests were used to present the associations between some selected variables in this study.

\section{RESULTS}

6.1. Participants' Skills

Figure1 presents the participants' skills in using technology as they indicated in the questionnaire. There were seven fields participants reported their abilities in. The majority of the students stated that they have an average ability in five skills. These five skills were: computer skills (48.7\%); skills to use virtual classrooms (39.4\%); skills to use virtual platforms (34.5\%); knowledge of security threats $(32.2 \%)$; and internet security procedures $(35.3 \%)$. However, the majority of participants reported high skills in two technical skills. These are how to use search engines (64.3\%) and email (51.7). 


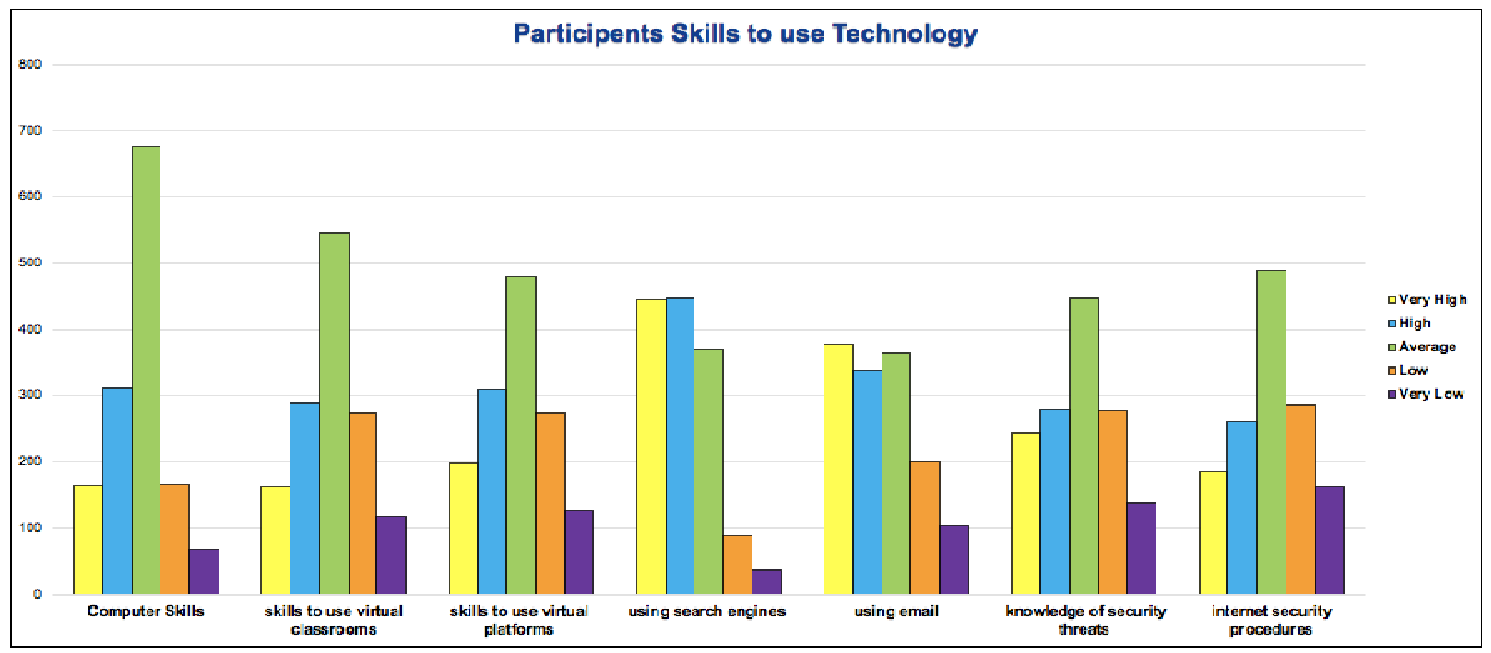

Figure 1. The Participants' Skills in Using Technology

\subsection{Participants' Attitudes}

This section of the questionnaire involves nine statements related to students' attitudes toward online learning. These statements were written in the form of a six-point Likert ranking scale. These scales were coded as strongly agree $=1$, agree $=2$, somewhat agree $=3$, somewhat disagree $=4$, disagree $=5$, and strongly disagree $=6$. This coding revealed that the students with higher value responses were more negative towards the statements than students with the lower -numbered answers.

Table 2 indicates the descriptive statistics (mean, median, mode and standard deviation) of each nine statements. The mode of all the statements was 1 (was recorded as strongly agree), which clearly showed that students' views towards using online learning were highly positive.

To put these statements in order, therefore, the values of the means of these nine statements were compared. This comparison displayed that the statement (I prefer Online learning rather than conventional learning) had the highest mean score $(M=1.2, S D=0.40)$. However, this statement demonstrated the least positive attitudes. Followed by (I feel satisfied during Online learning classrooms) $(M=1.15, S D=0.36)$, (I think the advantages of using online learning are more than its drawbacks) $(M=1.15, S D=0.36)$, and (Online learning increases the effectiveness of cooperation between learners) $(M=1.15, S D=0.35)$. The statement (I was able to share ideas with other learners during online classes) $(M=1.13, S D=0.34)$ was in third place. In the fourth place, (Online learning helped me gain the information at my convenient time) $(M=1.11, S D=0.32)$. Then, the statement (I got immediate answers to my questions while attending the online classes) $(M=1.10, S D=0.30)$. The lowest mean score $(M=1.09, S D=0.29)$ was recorded for the two statements (I effectively participate during online learning classes) and (Online learning helped me gain the information at my convenient place). This indicated that the most positive attitudes were recorded for these two statements.

Table 2. Descriptive Statistics

\begin{tabular}{|c|c|c|c|c|c|}
\hline Variables & $\mathbf{N}$ & Mean & Median & Mode & $\begin{array}{c}\text { Std. } \\
\text { Deviation }\end{array}$ \\
\hline $\begin{array}{l}\text { I prefer Online learning rather than conventional } \\
\text { learning }\end{array}$ & 1387 & 1.20 & 1 & 1 & 0.40 \\
\hline $\begin{array}{l}\text { I effectively participate during Online learning } \\
\text { classes }\end{array}$ & 1387 & 1.09 & 1 & 1 & 0.29 \\
\hline I feel satisfied during Online learning classrooms & 1387 & 1.15 & 1 & 1 & 0.36 \\
\hline $\begin{array}{l}\text { Online learning helped me gain the information at } \\
\text { my convenient time }\end{array}$ & 1387 & 1.11 & 1 & 1 & 0.32 \\
\hline $\begin{array}{l}\text { Online learning helped me gain the information at } \\
\text { my convenient place }\end{array}$ & 1387 & 1.09 & 1 & 1 & 0.29 \\
\hline $\begin{array}{l}\text { I got immediate answers to my questions while } \\
\text { attending the online classes }\end{array}$ & 1387 & 1.10 & 1 & 1 & 0.30 \\
\hline $\begin{array}{l}\text { I was able to share ideas with other learners during } \\
\text { online classes }\end{array}$ & 1387 & 1.13 & 1 & 1 & 0.34 \\
\hline $\begin{array}{l}\text { Online learning increases the effectiveness of } \\
\text { cooperation between learners }\end{array}$ & 1387 & 1.15 & 1 & 1 & 0.35 \\
\hline $\begin{array}{l}\text { I think the advantages of using online learning are } \\
\text { more than its drawbacks }\end{array}$ & 1387 & 1.15 & 1 & 1 & 0.36 \\
\hline
\end{tabular}


As stated before, all the nine statements in the questionnaire regarding students' attitudes consisted of six Likert scales. Therefore, these categories were combined into only two groups to make it easier for understanding students' views. These two categories are: Agree and disagree. Table 3 displays that most participants $(80 \%)$ agreed to use online learning rather than conventional learning, compared to $20 \%$ who disagreed. Additionally, 91\% of students reported that they participated effectively during Online learning classes. In contrast, only $9 \%$ did not. Most of the participants $(85 \%)$ felt satisfied during online learning classrooms compared to only $15 \%$ who reported that they did not feel happy.

Moreover, most students (89\%) found that online learning enabled them to access the material conveniently. On the other hand, only $11 \%$ of the participants did not believe that online learning provided them with time flexibility to access the courses materials. According to the flexibility that online learning may create, $91 \%$ of the learners who participated in the current study found that online learning allows them to access the courses materials from their preferred places. However, $9 \%$ of them refused the idea of the ability of online learning in providing place-related flexibility. The majority of the participants $(90 \%)$ agreed that they get immediate answers to their questions during the online courses. Only $10 \%$ of the participants elucidated that their questions during the online courses were not answered immediately. The majority of the participants agreed that online learning helped them share their ideas with their peers $(87 \%)$ and cooperate with other learners $(86 \%)$. Overall, most participants $(85 \%)$ agreed that online learning has advantages more than drawbacks. As a result, most Saudi Arabia students had great positive attitudes and preferred to use online learning during the Covide19 epidemic.

Table 3. Descriptive Statistics

\begin{tabular}{|c|c|c|c|c|c|}
\hline & & Frequency & $\begin{array}{l}\text { Per } \\
\text { cent }\end{array}$ & $\begin{array}{c}\text { Valid } \\
\text { Percent }\end{array}$ & $\begin{array}{c}\text { Cumulative } \\
\text { Percent }\end{array}$ \\
\hline \multirow{3}{*}{$\begin{array}{c}\text { Online learning better than conventional } \\
\text { learning }\end{array}$} & Agree & 1110 & 80 & 80 & 80 \\
\hline & Disagree & 277 & 20 & 20 & 100.0 \\
\hline & Total & 1387 & 100.0 & 100.0 & \\
\hline \multirow[t]{3}{*}{ Participation in online learning classes } & Agree & 1260 & 90.8 & 90.8 & 90.8 \\
\hline & Disagree & 127 & 9.2 & 9.2 & 100.0 \\
\hline & Total & 1387 & 100.0 & 100.0 & \\
\hline \multirow[t]{3}{*}{ Satisfaction in online learning classrooms } & Agree & 1174 & 84.6 & 84.6 & 84.6 \\
\hline & Disagree & 213 & 15.4 & 15.4 & 100.0 \\
\hline & Total & 1387 & 100.0 & 100.0 & \\
\hline \multirow[t]{3}{*}{ Online learning and flexibility of time } & Agree & 1232 & 88.8 & 88.8 & 88.8 \\
\hline & Disagree & 155 & 11.2 & 11.2 & 100.0 \\
\hline & Total & 1387 & 100.0 & 100.0 & \\
\hline \multirow[t]{3}{*}{ Online learning and flexibility of places } & Agree & 1260 & 90.8 & 90.8 & 90.8 \\
\hline & Disagree & 127 & 9.2 & 9.2 & 100.0 \\
\hline & Total & 1387 & 100.0 & 100.0 & \\
\hline \multirow{3}{*}{ Online learning and the immediate answers } & Agree & 1250 & 90.1 & 90.1 & 90.1 \\
\hline & Disagree & 137 & 9.9 & 9.9 & 100.0 \\
\hline & Total & 1387 & 100.0 & 100.0 & \\
\hline \multirow[t]{3}{*}{ Online learning and sharing ideas } & Agree & 1210 & 87.2 & 87.2 & 87.2 \\
\hline & Disagree & 177 & 12.8 & 12.8 & 100.0 \\
\hline & Total & 1387 & 100.0 & 100.0 & \\
\hline \multirow{3}{*}{$\begin{array}{l}\text { Online learning and cooperation between } \\
\text { learners }\end{array}$} & Agree & 1186 & 85.5 & 85.5 & 85.5 \\
\hline & Disagree & 201 & 14.5 & 14.5 & 100.0 \\
\hline & Total & 1387 & 100.0 & 100.0 & \\
\hline \multirow[t]{3}{*}{ Online learning advantages/drawbacks } & Agree & 1181 & 85.1 & 85.1 & 85.1 \\
\hline & Disagree & 206 & 14.9 & 14.9 & 100.0 \\
\hline & Total & 1387 & 100.0 & 100.0 & \\
\hline
\end{tabular}


Difficulties encountered by Participants

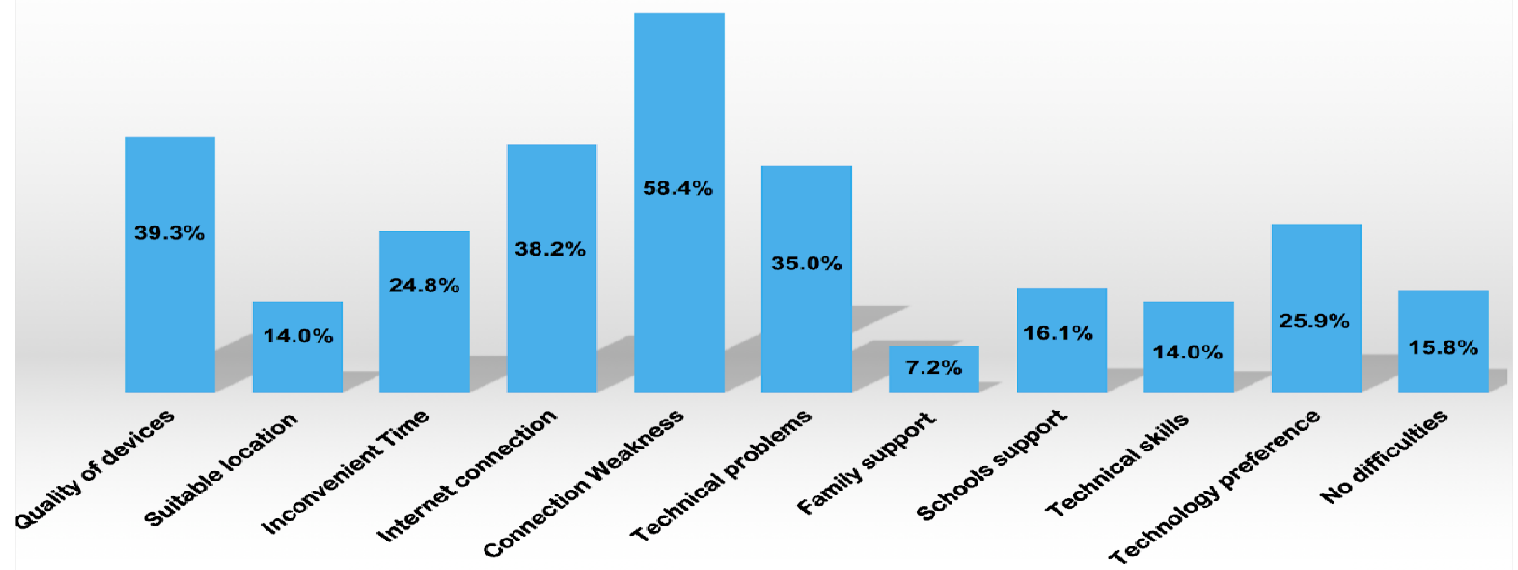

Figure 2. The difficulties that were indicated by participants

The majority of the participants $(58.4 \%)$ indicated that the weakness of the internet connection was the tophighest difficulty that faced them during online learning. The second-highest challenge was the unavailability of good quality devices $(39.3 \%)$ followed by the unavailability of the internet connection $(38.2 \%)$. The fourth difficulty was that participants were unable to tackle technical problems (35\%). However, the bottom four difficulties that faced students were: lack of schools' support (16.1\%); Unavailability of a suitable location to study online; and lack of technical skills in using technology with (14\%) each; and lack of family support $(7.2 \%)$.

The inconvenience of class time was another challenge chosen by $24.8 \%$ of the participants. In addition, $25.9 \%$ of the students showed an unwillingness to use technology in their education. Only $15.8 \%$ of the participants indicated that they did not have any problems using technology during online classes.

6.4. Gender and students' technical competencies in using online learning

Table 4. Associations between gender and students' abilities in using online learning

\begin{tabular}{|c|c|c|c|c|}
\hline \multirow[t]{2}{*}{$\begin{array}{l}\text { First } \\
\text { variable }\end{array}$} & \multirow[t]{2}{*}{ Second Variable } & \multicolumn{2}{|c|}{$\begin{array}{l}\text { Statistical tests to examine the significance of } \\
\text { associations }\end{array}$} & \multirow[t]{2}{*}{$\begin{array}{l}\text { Level of } \\
\text { Significance }\end{array}$} \\
\hline & & Chi-square score & Fisher's Exact Test & \\
\hline \multirow{7}{*}{ Gender } & Computer skills & $\begin{array}{c}{[\chi 2(2, \mathrm{~N}=1387)=55.80} \\
\mathrm{p}<0.001]\end{array}$ & {$[\chi 2=55.93 ; p<0.001]$} & $\begin{array}{c}\text { High } \\
\text { significant }\end{array}$ \\
\hline & $\begin{array}{l}\text { Using virtual } \\
\text { classrooms }\end{array}$ & $\begin{array}{c}{\left[\chi^{2}(2, \mathrm{~N}=1387)=114.95\right.} \\
\mathrm{p}<0.001]\end{array}$ & {$\left[\chi^{2}=117.90 ; \mathrm{p}<0.001\right]$} & $\begin{array}{c}\text { High } \\
\text { significant }\end{array}$ \\
\hline & $\begin{array}{l}\text { Using virtual } \\
\text { platforms }\end{array}$ & $\begin{array}{c}{[\chi 2(2, \mathrm{~N}=1387)=48.27} \\
\mathrm{p}<0.001]\end{array}$ & {$\left[\chi^{2}=48.63 ; p<0.001\right]$} & $\begin{array}{c}\text { High } \\
\text { significant }\end{array}$ \\
\hline & $\begin{array}{c}\text { Using search } \\
\text { engine }\end{array}$ & $\begin{array}{c}{\left[\chi^{2}(2, \mathrm{~N}=1387)=54.095\right.} \\
\mathrm{p}<0.001]\end{array}$ & {$[\chi 2=54.37 ; \mathrm{p}<0.001]$} & $\begin{array}{c}\text { High } \\
\text { significant }\end{array}$ \\
\hline & Using email & $\begin{array}{c}{\left[\chi^{2}(2, \mathrm{~N}=1387)=108.98\right.} \\
\mathrm{p}<0.001]\end{array}$ & {$\left[\chi^{2}=110.13 ; \mathrm{p}<0.001\right]$} & $\begin{array}{c}\text { High } \\
\text { significant }\end{array}$ \\
\hline & $\begin{array}{c}\text { Knowledge of } \\
\text { security threats }\end{array}$ & $\begin{array}{c}{\left[\chi^{2}(2, \mathrm{~N}=1387)=21.86\right.} \\
\mathrm{p}<0.001]\end{array}$ & {$[\chi 2=21.87 ; \mathrm{p}<0.001]$} & $\begin{array}{c}\text { High } \\
\text { significant }\end{array}$ \\
\hline & $\begin{array}{l}\text { Internet security } \\
\text { procedures }\end{array}$ & $\begin{array}{c}{\left[\chi^{2}(2, \mathrm{~N}=1387)=17.69\right.} \\
\mathrm{p}<0.001]\end{array}$ & {$[\chi 2=17.79 ; \mathrm{p}<0.001]$} & $\begin{array}{c}\text { High } \\
\text { significant }\end{array}$ \\
\hline
\end{tabular}


Table 5. Gender and ICT skills

\begin{tabular}{|c|c|c|c|c|}
\hline \multirow{2}{*}{ Gender } & \multicolumn{3}{|c|}{ Technical competencies in using computer } & \multirow[b]{2}{*}{ Total } \\
\hline & High & Average & Low & \\
\hline Female & 165 & 300 & 151 & 616 \\
\hline Male & 311 & 376 & 84 & 771 \\
\hline Total & 476 & 676 & 235 & 1387 \\
\hline \multirow{2}{*}{ Gender } & \multicolumn{4}{|c|}{ Using virtual classrooms } \\
\hline & High & Average & Low & Total \\
\hline Female & 117 & 256 & 243 & 616 \\
\hline Male & 334 & 291 & 146 & 771 \\
\hline Total & 451 & 547 & 389 & 1387 \\
\hline \multirow{2}{*}{ Gender } & \multicolumn{4}{|c|}{ Using a search engine } \\
\hline & High & Average & Low & Total \\
\hline Female & 343 & 183 & 90 & 616 \\
\hline Male & 549 & 186 & 36 & 771 \\
\hline Total & 718 & 892 & 369 & 126 \\
\hline \multirow{2}{*}{ Gender } & \multicolumn{4}{|c|}{ Using emails } \\
\hline & High & Average & Low & Total \\
\hline Female & 226 & 194 & 196 & 616 \\
\hline Male & 492 & 170 & 109 & 771 \\
\hline Total & 718 & 364 & 305 & 1387 \\
\hline \multirow{2}{*}{ Gender } & \multicolumn{4}{|c|}{ Knowledge of security threats } \\
\hline & High & Average & Low & Total \\
\hline Female & 197 & 200 & 219 & 616 \\
\hline Male & 328 & 247 & 196 & 771 \\
\hline Total & 525 & 447 & 415 & 1387 \\
\hline \multirow{2}{*}{ Gender } & \multicolumn{4}{|c|}{ Internet security procedures } \\
\hline & High & Average & Low & Total \\
\hline Female & 164 & 227 & 225 & 616 \\
\hline Male & 284 & 263 & 224 & 771 \\
\hline Total & 448 & 490 & 449 & 1387 \\
\hline \multirow{2}{*}{ Gender } & \multicolumn{4}{|c|}{ Using virtual platforms } \\
\hline & High & Average & Low & Total \\
\hline Female & 281 & 205 & 130 & 616 \\
\hline Male & 227 & 273 & 271 & 771 \\
\hline Total & 508 & 478 & 401 & 1387 \\
\hline
\end{tabular}

According to Table 4 , there was a highly significant association $[\chi 2(2, \mathrm{~N}=1387)=55.80, \mathrm{p}<0.001]$ between gender and students' technical competencies in using a computer. In other words, male and female participants demonstrated significant different degrees of competence in using computers in Saudi Arabia. Table 5 indicates that male students $(40 \%)$ reported a higher ability than females $(27 \%)$ in using computers. Whereas only $11 \%$ of male students classified their ability in using a computer as low compared with females (25\%). Therefore, male students had higher technical skills, as they reported, than females.

Moreover, there was a highly significant association $[\chi 2(2, \mathrm{~N}=1387)=114.95, \mathrm{p}<0.001]$ between gender and using virtual classrooms (Table 4). This indicates a significant difference between males and females regarding their ability to use virtual classrooms. Table 5 shows that male students $(43 \%)$ reported higher skills in using virtual classrooms than females (19\%). 39\% of females classified their skills in virtual classrooms as low compared with only $19 \%$ of males. As a result, female students showed lower abilities than males regarding using virtual classrooms.

Similarly, according to Table 4, there were high significant associations between gender and using virtual platforms $[\chi 2(2, \mathrm{~N}=1387)=48.27, \mathrm{p}<0.001]$, using search engine $[\chi 2(2, \mathrm{~N}=1387)=54.095, \mathrm{p}<0.001]$, using emails $[\chi 2(2, N=1387)=108.98, p<0.001]$, Knowledge of security threats $[\chi 2(2, N=1387)=21.86, p<0.001]$, and Internet security procedures $[\chi 2(2, \mathrm{~N}=1387)=17.69, \mathrm{p}<0.001]$.

As indicated in Table 5, male students reported higher skills in using a search engine (71\%), using emails (64\%), knowledge of security threats (43\%), and Internet security procedures (32\%) than females. However, female students (46\%) reported higher competencies in using virtual platforms than males (29\%). While $35 \%$ of male students reported low skills in using virtual platforms compared to only (21\%) of females. Thus, female students had more competencies in using virtual platforms than males. 
6.5. Gender and the attitudes towards using online learning

Table 6. Associations between gender and the attitudes towards using online learning

\begin{tabular}{|c|c|c|c|c|}
\hline \multirow[t]{2}{*}{$\begin{array}{l}\text { First } \\
\text { variable }\end{array}$} & \multirow[t]{2}{*}{$\begin{array}{l}\text { Second Variable } \\
\text { Attitudes }\end{array}$} & \multicolumn{2}{|c|}{$\begin{array}{l}\text { Statistical tests to examine the } \\
\text { significance of associations }\end{array}$} & \multirow[t]{2}{*}{$\begin{array}{c}\text { Level of } \\
\text { Significance }\end{array}$} \\
\hline & & Chi-square score & $\begin{array}{c}\text { Fisher's Exact } \\
\text { Test }\end{array}$ & \\
\hline \multirow{9}{*}{ Gender } & $\begin{array}{c}\text { Online learning better than } \\
\text { conventional learning }\end{array}$ & $\begin{array}{l}{[\chi 2(3, \mathrm{~N}=1387)} \\
=51.2, \mathrm{p}<0.001]\end{array}$ & $\begin{array}{c}{[\chi 2=52.7} \\
\mathrm{p}<0.001]\end{array}$ & High significant \\
\hline & $\begin{array}{c}\text { Participation in online learning } \\
\text { classes }\end{array}$ & $\begin{array}{l}{[\chi 2(3, \mathrm{~N}=1387)} \\
=8.09, \mathrm{p}<0.05]\end{array}$ & $\begin{array}{c}{\left[\chi^{2}=8.15\right.} \\
\mathrm{p}=0.04]\end{array}$ & significant \\
\hline & $\begin{array}{c}\text { Satisfaction in online learning } \\
\text { classrooms }\end{array}$ & $\begin{array}{l}{[\chi 2(3, \mathrm{~N}=1387)} \\
=30,53, \mathrm{p}<0.001]\end{array}$ & $\begin{array}{c}{\left[\chi^{2}=31.25\right.} \\
\mathrm{p}<0.001]\end{array}$ & High significant \\
\hline & $\begin{array}{c}\text { Online learning and flexibility of } \\
\text { time }\end{array}$ & $\begin{array}{l}{[\chi 2(3, \mathrm{~N}=1387)} \\
=37.46, \mathrm{p}<0.001]\end{array}$ & $\begin{array}{c}{\left[\chi^{2}=38.53\right.} \\
\mathrm{p}<0.001]\end{array}$ & High significant \\
\hline & $\begin{array}{c}\text { Online learning and flexibility of } \\
\text { places }\end{array}$ & $\begin{array}{l}{[\chi 2(3, \mathrm{~N}=1387)} \\
=58.14, \mathrm{p}<0.001]\end{array}$ & $\begin{array}{c}{\left[\chi^{2}=60.20\right.} \\
\mathrm{p}<0.001]\end{array}$ & High significant \\
\hline & $\begin{array}{l}\text { Online learning and the } \\
\text { immediate answers }\end{array}$ & $\begin{array}{l}{[\chi 2(3, \mathrm{~N}=1387)} \\
=39.18, \mathrm{p}<0.001]\end{array}$ & $\begin{array}{c}{\left[\chi^{2}=40.08\right.} \\
\mathrm{p}<0.001]\end{array}$ & High significant \\
\hline & Online learning and sharing ideas & $\begin{array}{l}{\left[\chi^{2}(3, \mathrm{~N}=1387)\right.} \\
=57.90, \mathrm{p}<0.001]\end{array}$ & $\begin{array}{c}{\left[\chi^{2}=60.15\right.} \\
\mathrm{p}<0.001]\end{array}$ & High significant \\
\hline & $\begin{array}{c}\text { Online learning and cooperation } \\
\text { between learners }\end{array}$ & $\begin{array}{l}{[\chi 2(3, \mathrm{~N}=1387)} \\
=46.03, \mathrm{p}<0.001]\end{array}$ & $\begin{array}{c}{\left[\chi^{2}=47.69\right.} \\
\mathrm{p}<0.001]\end{array}$ & High significant \\
\hline & $\begin{array}{l}\text { Advantages of Online learning } \\
\text { are more than drawbacks }\end{array}$ & $\begin{array}{l}{[\chi 2(3, \mathrm{~N}=1387)} \\
=42.52, \mathrm{p}<0.001]\end{array}$ & $\begin{array}{c}{[\chi 2=43.59} \\
\mathrm{p}<0.001]\end{array}$ & High significant \\
\hline
\end{tabular}

Table 7. Gender and the attitudes towards using online learning

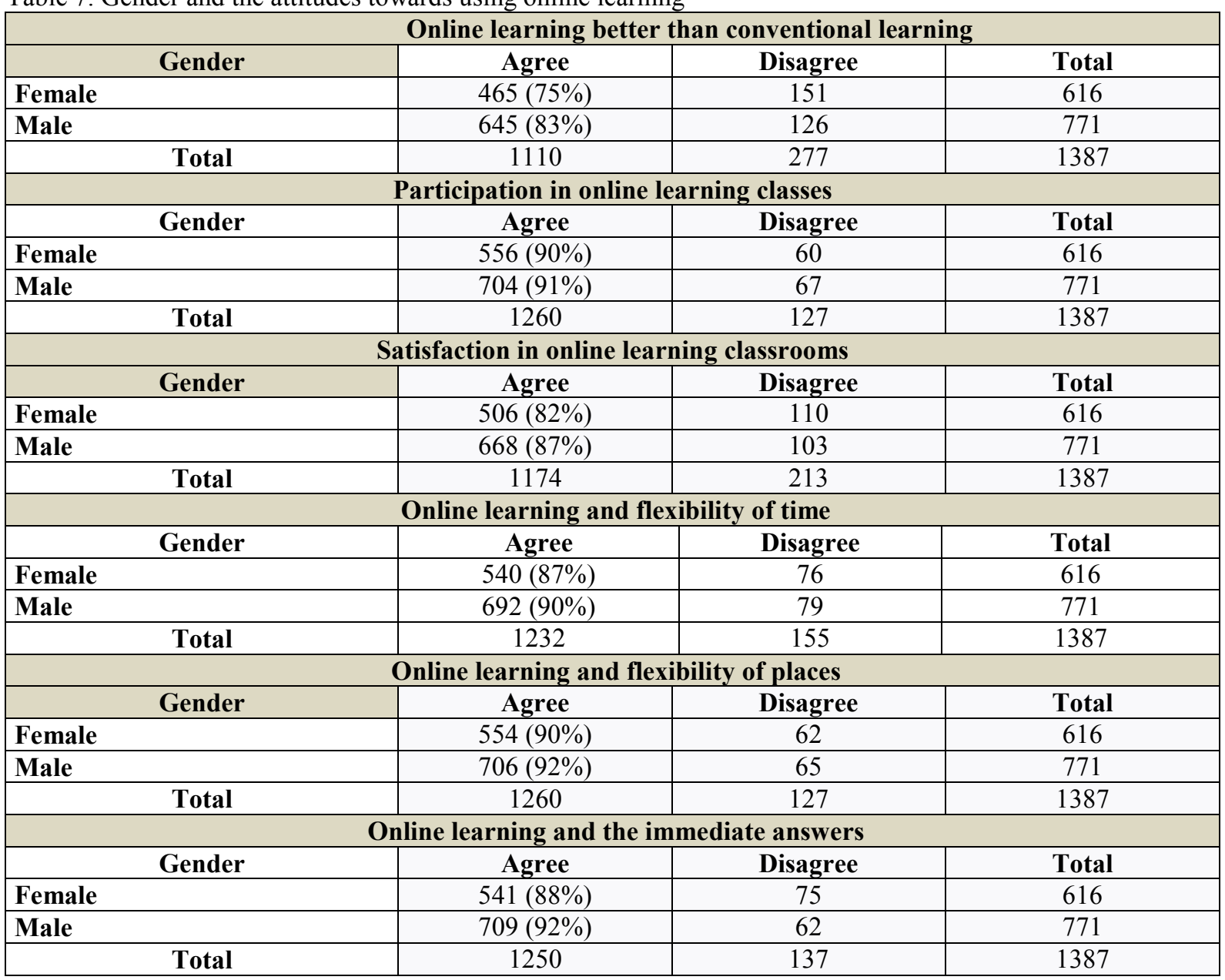




\begin{tabular}{|c|c|c|c|}
\hline \multicolumn{4}{|c|}{ Online learning and sharing ideas } \\
\hline Gender & Agree & Disagree & Total \\
\hline Female & $522(85 \%)$ & 94 & 616 \\
\hline Male & $688(89 \%)$ & 83 & 771 \\
\hline Total & 1210 & 177 & 1387 \\
\hline \multicolumn{4}{|c|}{ Online learning and cooperation between learners } \\
\hline Gender & Agree & Disagree & Total \\
\hline Female & $515(84 \%)$ & 101 & 616 \\
\hline Male & $671(87 \%)$ & 100 & 771 \\
\hline Total & 1186 & 201 & 1387 \\
\hline \multicolumn{4}{|c|}{ The advantages of online learning are more than the drawbacks } \\
\hline Gender & Agree & Disagree & Total \\
\hline Female & $514(83 \%)$ & 102 & 616 \\
\hline Male & $667(87 \%)$ & 104 & 771 \\
\hline Total & 1181 & 206 & 1387 \\
\hline
\end{tabular}

According to Table 6 , a highly significant association $[\chi 2(3, \mathrm{~N}=1387)=51.2, \mathrm{p}<0.001]$ was shown between gender and the statement (Online learning better than conventional learning). Similarly, there were high significant associations between gender and the statements (Satisfaction in online learning classrooms) $[\chi 2(3$, $\mathrm{N}=1387)=30,53, \mathrm{p}<0.001]$, (Online learning and flexibility of time $)[\chi 2(3, \mathrm{~N}=1387)=37.46, \mathrm{p}<0.001]$, (Online learning and flexibility of places $)\left[\chi^{2}(3, \mathrm{~N}=1387)=58.14, \mathrm{p}<0.001\right]$, (Online learning and the immediate answers $)[\chi 2(3, \mathrm{~N}=1387)=39.18, \mathrm{p}<0.001],($ Online learning and sharing ideas $)[\chi 2(3, \mathrm{~N}=1387)=57.90$, $\mathrm{p}<0.001]$, (Online learning and cooperation between learners) $\left[\chi_{2}(3, \mathrm{~N}=1387)=46.03, \mathrm{p}<0.001\right]$, and (Advantages of online learning are more than drawbacks) $[\chi 2(3, \mathrm{~N}=1387)=42.52, \mathrm{p}<0.001]$. A significant association indicated between gender and the statement (Participation in online learning classes) $[\chi 2(3, \mathrm{~N}=1387)$ $=8.09, \mathrm{p}<0.05]$.

This association demonstrates a significant difference between males and females regarding their views about online learning. According to Table 7, the percentages of males who agreed about all the nine statements regarding the attitudes were higher than females. This indicates that male students had higher positive views about using online learning during the time of this study.

\section{DISCUSSION}

7.1. What are the views of students towards using online learning during the coronavirus epidemic in Saudi Arabia?

This study finds that students showed positive attitudes to the online classroom. This positive view is echoed in much previous research (e.g. Bichi et al., 2017; Chin, 2013; Webb \& Doman, 2020). The highest percentage $(80 \%)$ agrees that online learning is better than conventional learning. The result shows that most participants agreed that online learning helped them attend their classes conveniently (88.8\%) and convenient place (90.8\%). This result echoes the finding of Cook et al. (2010). They found that online learning can enhance learners' control over three elements (i.e. curriculum content, learning location and learning timing and duration).

In the same way, most participants $(87.2 \%)$ believed that online learning supports sharing ideas, $85.5 \%$ believed that online learning increases the level of cooperation between learners, and $90.1 \%$ of the participants agreed that online learning helped them receive immediate answers when they needed them. Those beliefs are in line with the finding of Balaji (2010), who reported that the use of online discussion forums created chances for learners to progressively communicate with other learners, teachers, course contents and learning resources. Furthermore, Bloom and Sherlock (2007) found that increased interaction between faculty and students results in an increased satisfaction level for online learners. The major of the participants $(90.8 \%)$ stated that they had participated effectively in the online classroom. Also, many participants $(84.6 \%)$ found that the online classes were interesting, and they were pleased during those classes. In the same way, Ozkara and Cakir (2018) found that one of the advantages their participants express was that the online courses were joyful. However, this finding is contrary to the results of Williams and Pury (2002), whose participants found that the online courses were not enjoyable.

\subsection{What difficulties and challenges faced students in using online learning during the corona virus epidemic in Saudi Arabia?}

This part aims to find the different difficulties encountered by the learners during online classes in the Covid 19 period. The results showed that the top-highest problems encountered students were technical-related difficulties. The technical difficulties revealed by the current study can be divided into two groups. The first group included 
technologies as tools (e.g. weaknesses or absent of internet connection, and unavailability of good quality devices). The other group related to the learners as users (e.g. the learners' weak technical skills), which can be improved through extra efforts and trainings. The technical difficulties demonstrated by the current results match the findings of (Alebaikan \& Troudi, 2010; Ramos et al., 2011; Heaney \& Walker, 2012; Bloomfield \& Jones, 2013).

\subsection{Are there gender-related differences in students' competencies in using online learning during the coronavirus epidemic in Saudi Arabia?}

According to the findings of this study, male and female students in Saudi Arabia demonstrated significant different degrees of technical competencies in using computers $[\chi 2(2, \mathrm{~N}=1387)=55.80, \mathrm{p}<0.001]$ (Table 4). In this study, male students had higher technical skills as they reported than females (Table 5). This finding is inconsistent with the finding of Aesaert \& Braak (2015), whose research showed that girls are better than boys in ICT skills

Moreover, in the current study, there was a significant difference between males and females regarding their ability in using virtual classrooms $\left[\chi^{2}(2, \mathrm{~N}=1387)=114.95, \mathrm{p}<0.001\right]$ (Table 4). Male students $(43 \%)$ reported that they had higher skills in using virtual classrooms than females (19\%) (Table 5). Similarly, male students reported higher skills in using a search engine (71\%), using emails (64\%), knowledge of security threats (43\%), and Internet security procedures (32\%) than females (Table 5). However, female students (46\%) reported higher competencies in using virtual platforms than males (29\%). In the same view, McSporran and Young (2001) found that girls surpass boys during their web-based classes. However, the study that was conducted by Alexander et al. (2011) showed that gender did not affect any of the internet skills.

\subsection{Are there gender-related differences in attitudes towards using online learning during the coronavirus epidemic in Saudi Arabia?}

In this study, nine statements were written to express the attitudes towards using online learning. According to Table 6, there were high significant associations between gender and the eight statements: (Online learning better than conventional learning), (Online learning better than conventional learning), (Satisfaction in online learning classrooms), (Online learning and flexibility of time), (Online learning and flexibility of places), (Online learning and the immediate answers), (Online learning and sharing ideas), (Online learning and cooperation between learners), and (Advantages of online learning are more than drawbacks). Moreover, a significant association appeared between gender and the statement (Participation in online learning classes) (Table 6).

Thus, the findings of this study indicated that there were significant differences between males and females regarding their views about online learning (Table 6). The percentages of males who agreed about all the nine statements regarding the attitudes were higher than females (Table 7). This indicates that male students had higher positive views about using online learning than females during this study.

This finding agreed with the finding of the meta-analysis of Cai et al. (2016), in which males showed higher attitudes toward ICT use than females. However, the outcome of Liang et al. (2015) showed that female learners were more able to provide further elaboration than males in web-based discussions. Moreover, the finding of a study conducted by $\mathrm{Xu} \&$ Jaggars (2011) proved that female learners show more inclination to join online courses more than male learners.

Nevertheless, Sarfo et al. (2011), in their study to explore senior high school learners' attitudes towards information and communication technology (ICT), showed no gender-related difference in the participants' attitudes. However, urban learners had more positive attitudes towards ICT than those who came from rural areas.

\section{CONCLUSION}

This study aimed to investigate students' attitudes towards using online learning and the challenges facing them during the coronavirus epidemic in Saudi Arabia. 1387 students (616 females and 771 males) participated in the current study. Those students were from different school stages from elementary to postgraduate level. The main findings of this study indicated that the majority of the participants reported that they had an average ability in five ICT skills and high ability in two ICT skills.

Additionally, most students showed high positive attitudes to their experiments in using online learning during the Covid19 period. However, male students had higher positive views about using online learning than females during this study.

Furthermore, the top-highest difficulties that faced students during online learning were the weakness of the internet connection, unavailability of good quality devices, unavailability of the internet connection for some students, and technical problems.

Moreover, the results have uncovered gender-related differences in students' ICT competencies and their 
attitudes towards using online learning. Male students in this study reported that they had higher skills in using computers, using virtual classrooms, using a search engine, using emails, knowledge of security threats, and internet security procedures than females. However, female students had higher competencies in using virtual platforms than males. Furthermore, as indicated previously, male students had higher positive views about using online learning than females.

The outcomes of this study could improve the online learning system in Saudi Arabia and improve students' skills and teachers' professional development programs that relate to using online learning.

Indeed, the use of online learning during the Coronavirus epidemic in Saudi Arabia was the right solution that shows that the Ministry of Education has high potential and the ability to face this problem. Students accepted using online learning based on the findings of this study. However, they need to improve their skills in using online learning by training them during school time, aiming to ensure that students are ready to use online learning. Consequently, it is recommended that Saudi schools should use both traditional and online learning (Blended Learning) regularly in their educational system.

\section{ACKNOWLEDGEMENT}

We would like to express appreciation to all the participants who took the time to contribute in this study. Indeed, their collaboration in completing the questionnaire and joining the interviews was very helpful to give a clear picture about their views, skills, and the complications faced while using online learning.

\section{References}

Abedalaziz, N., Jamaluddin, S. \& Chin, H. L. (2013). Measuring Attitudes Toward Computer and Internet Usage Among Postgraduate Students in Malaysia. Turkish Online Journal of Educational Technology, 12 (2).

Aesaert, K., \& Van Braak, J. (2015). Gender and socioeconomic related differences in performance-based ICT competencies. Computers \& Education, 84, 8-25. http:// dx.doi.org/10.1016/j.compedu.2014.12.017.

Al-Qahtani, I. (2011). The Status of the using of virtual classrooms in distance learning program from the point of view of faculty members at King Abdulaziz University in Jeddah. Jeddah: King Abdulaziz University.

Anderson, T. (2004). Toward a theory of online learning. In T. Anderson \& F. Elloumi (Eds), Theory and practice of online learning (pp.33-60). Athabasca, AB: Athabasca University.

Arbaugh, J. (2010). Sage, guide, both, or even more? An examination of instructor activity in online MBA courses. Communication Education, 55(3), 1234-1244.

Balaji, M. S., \& Chakrabarti, D. (2010). Student Interactions in Online Discussion Forum: Empirical Research from 'Media Richness Theory' Perspective. Journal of Interactive Online Learning, 9(1), 1-22

Bichi, A. A., Embong, R., \& Rashid, R. A. (2017). Nigerian postgraduate students' attitude and perceived competence in using ICT resources for research purpose. Journal of Nusantara Studies (JONUS), 2(2), 224230.

Carliner, Saul. (2004). An Overview of Online Learning (2nd ed.). European Business Review. 16. $10.1108 / 09555340410561723$

Cook, D.A., Levinson, A.J. \& Garside, S. (2010) Time and learning efficiency in Internet-based learning: a systematic review and meta-analysis. Advance in Health Science Education. 15 (5), 755-770

Creswell, J.W., Plano Clark, V.L., Gutmann, M. \& Hanson, W. (2003) 'Advanced mixed methods research designs', in Tashakkori, A. and Teddlie, C. (eds.) Handbook of mixed methods in social \& behavioral research. Thousand Oaks, CA: Sage, pp. 209-240.

Daft, R. L., \& Lengel, R. H. (1986). Organizational information requirements, media richness, and structural design. Management Science, 32(5), 554-571.

Dahlstrom-Hakki, I., Alstad, Z., \& Banerjee, M. (2020). Comparing synchronous and asynchronous online discussions for students with disabilities: the impact of social presence. Computers \& Education, 150, 103842.

Guglielmino, L. M., \& Guglielmino, P. J. (2003). Identifying learners who are ready for e-learning and supporting their success. Preparing learners for e-learning, 18-33.

Hameed, S., Badii, A., \& Cullen, A. J. (2008). Effective e-learning integration with traditional learning in a blended learning environment. In European and Mediterranean Conference on Information Systems (pp. 25-26).

Hone, K. S., \& El Said, G. R. (2016). Exploring the factors affecting MOOC retention: A survey study. Computers \& Education, 98, 157-168.

Huss, J. A., \& Eastep, S. (2013). The perceptions of students toward online learning at a Midwestern university: What are students telling us and what are we doing about it? I.e., inquiry in education, 4(2), 5.

Jebur, M. S. (2020). The Use of Mobile-Assisted Language Learning (MALL) by Iraqi EFL College Students' and their Attitudes Towards it. Journal of University of Babylon for Humanities, 28(2), 150-160.

Lowenthal, P. \& Wilson, B.G. (2010). Labels do matter! A critique of AECT's redefinition of the field. Tech 
Trends, 54(1),

Lowes, S., Lin, P., \& Kinghorn, B. (2016). Gender differences in online high school courses. Online Learning, 20(4), 100-117. https://doi.org/10.24059/olj.v20i4.1049

Marc, J. R. (2002). Book review: e-learning strategies for delivering knowledge in the digital age. Internet and Higher Education, 5, 185-188.

Means, B., Toyama, Y., Murphy, R., Bakia, M., \& Jones, K. (2009). Evaluation of evidence-based practices in online learning: A meta-analysis and review of online learning studies. Washington, DC: US Department of Education.

Mehran, P., Alizadeh, M., Koguchi, I., \& Takemura, H. (2017). Are Japanese digital natives ready for learning English online? A preliminary case study at Osaka University. International Journal of Educational Technology in Higher Education, 14(1), 8.

Moore, M. G. (2013). The theory of transactional distance. In M. G. Moore (Ed.), Handbook of distance education (3rd ed., pp. 66-85). Mahwah, NJ: Lawrence Erlbaum. http://dx.doi.org/10.4324/9780203803738.ch5

Oh, Y. \& Lee, S. M. (2016). The Effects of Online Interactions on the Relationship Between Learning-Related Anxiety and Intention to Persist Among E-Learning Students with Visual Impairment. International Review of Research in Open and Distributed Learning, 17 (6), 89-107.

Online.columbusstate.edu. (2020) Smarter measure Assessment. [online] Available at: $<$ https://online.columbusstate.edu/smarter_measure.php $>$ [Accessed 9 June 2020].

Ozaydın Ozkara, B., \& Cakir, H. (2018). Participation in online courses from the students' perspective. Interactive Learning Environments, 26(7), 924-942. https://doi.org/10.1080/10494820.2017.1421562

Sarfo, F. K., Amartei, A. M., Adentwi, K. I., \& Brefo, C. (2011). Technology and gender equity: Rural and urban students' attitudes towards information and communication technology. Journal of Media and Communication Studies, 3(6), 221.

Tsai, M.-J., Liang, J.-C., Hou, H.-T., \& Tsai, C.-C. (2015). Males are not as active as females in online discussion: Gender differences in face-to-face and online discussion strategies. Australasian Journal of Educational Technology, 31(3), 263-277. http://ajet.org.au/index.php/AJET/article/view/1557/1278

Webb, M.; Doman, E. (2019) Impacts of flipped classrooms on learner attitudes towards technology-enhanced language learning. Comput. Assist. Lang. Learn, 1-35.

Williams, S. \& Pury, C. (2002). Student Attitudes toward and Participation in Electronic Discussion. International Journal of Educational Technology, 3(1), Retrieved April 28, 2020, from https://ascilite.org/archived-journals/ijet/v3n1/williams/.

Wladis, C., Conway, K. M., \& Hachey, A. C. (2015). The online STEM classroom-Who succeeds? An exploration of the impact of ethnicity, gender, and non-traditional student characteristics in the community college context. Community College Review, 43(2), 142-164.

Xing, W. J., Ao, L. J., Xiao, H. T., \& Liang, L. (2020). Chinese nurses' preferences for and attitudes about elearning in continuing education: A correlational study. Journal of Continuing Education in Nursing, 51(2), 87-96.

Xu, D., \& Jaggars, S. S. (2011). Online and hybrid course enrollment and performance in Washington State Community and Technical Colleges (CCRC Working Paper No. 31). Community College Research Center, Columbia University. Retrieved from http://files.eric.ed.gov/fulltext/ED517746.pdf

Xu, D., \& Jaggars, S. (2013). Adaptability to online learning: Differences across types of students and academic subject areas. CCRC Working Paper No. 54. Retrieved September 5, 2013, from http://ccrc.tc.columbia.edu/media/k2/attachments/adaptability-to-online-learning.pdf 